\title{
The Relationship between Core Resources and Strategies of Firms: The Case of Sri Lankan Value-Added Tea Producers
}

\author{
A. Ariyawardana and W.C. Bailey ${ }^{*}$
}

\begin{abstract}
Even though the strategy and resource-based views separately argue that superior performance is influenced by strategies and resources of firms, this study argues that there can be an indirect relationship between the core resources and strategies of firms. The strength of this relationship was examined based on a set of data gathered from a group of value-added tea producers in Sri Lanka. The cannonical analysis revealed a significant relationship between strategy and resource patterns; however, resource patterns explained only 21 per cent of the variance of the strategy patterns. This indicated that the Sri Lankan value-added tea producing firms' choice of, and ability to perform a particular strategy are weakly associated with their core resource strength.
\end{abstract}

\section{Introduction}

Strategy-based views (SBV) and resource-based views (RBV) can be considered as the two dominant views that emerged in explaining firm performance through the competitive advantage paradigm. These two views argue that a firm can gain competitive advantage and thereby achieve a superior performance by the execution of superior strategies and by the possession of unique resources respectively. Even though the final outcome, superior performance, is the same from both perspectives, the researchers viewed it from those of the strategies and resources of a firm. Similarly, to the two direct relationships mentioned above, there could also be a relationship between core resources and performance via core strategies. That is, there could also be a relationship between core resources and strategies of firms or there could be a relationship between the two perspectives: RBV and SBV. Accordingly, it can be argued that the ability of a firm to pursue a particular strategy is dependent on what resources that firm has. That is,

The authors are, respectively, Senior Lecturer in Agricultural Economics, University of Peradeniya, and Professor of Agribusiness, Massey University, New Zealand. 
the choice and the ability to perform a particular strategy can be highly dependent on the resource strength of a firm. Therefore, this study was conducted with a view to examining whether there is a relationship between core resources and strategies of firms and, if any, to determine the strength of the relationship.

\section{Strategy- and Resource-Based Views}

Porter's generic competitive strategy view gave the most substantial contribution to the SBV when he considered two basic types of competitive advantage: low-cost and differentiation (Porter, 1998). Even though Porter considered that these two strategies are basically incompatible, many questioned their mutual exclusiveness (Phillips, Chang and Buzzel, 1983; Hendry, 1990; Miller, 1992). Therefore, the identification of a wider range of strategic options at the value chain level is considered to be good as it provides more flexibility in planning and reaching the goal of superior firm performance (Faulkner and Bowman, 1992; Miller and Dess, 1993). Unlike SBV which stresses the importance of choosing a product market position, the RBV raises the importance of firm resources and capabilities in competition and the theoretical background was strengthened by the work done by many researchers (Wernerfelt, 1984; Barney, 1991; Grant, 1991; Peteraf 1993; Collis, 1994). In all these studies, the competitive advantage of a firm was viewed through the resource aspect where resources were defined as anything which could be thought of as a strength or weakness of a given firm (Wernerfelt, 1984). But Barney (1991) pointed out that a firm could achieve a competitive advantage only if the resources have attributes: they must be valuable, rare, imperfectly imitable and there cannot be strategically equivalent substitutes.

Even though, RBV was raised due to the weaknesses in the market driven approaches in achieving a superior performance, Haanes and Fjelstad (2000) by examining the pharmaceutical industry based on the RBV and SBV argued that both perspectives are complementary. They concluded that it is essential to incorporate both views - since value creation result from the activities in which the resources are applied. A similar argument was raised by Day and Wensley (1988) when they pointed out that sources of competitive advantage are important in determining positional advantage. Performance outcomes are considered to be a consequence of relative superiority in the skills and resources a business deploys due to positional advantages. Similarly, 
Bharadwaj, Varadarajan and Fahy (1993), by developing a contingency model of sustainable competitive advantage for service industries, argued that superior skills and resources do not automatically give a business a competitive advantage. They indicated that they provide only an opportunity for it to leverage its skills and resources to achieve cost and/or differentiation advantage. However, almost all the studies have used individual perspectives in assessing firm performance (Wagner and Digman, 1997; Dess et al., 1997; Kamalesh et al., 1997; Miller and Shamsie, 1996; Majumdar, 1998; Wolff and Pett, 2000) and none of the studies conducted so far has tested the relationship between these two views. Therefore, this study was conducted with the aim of examining the link between the two views: RBV and SBV.

\section{Data Collection}

This study was conducted based on data gathered from a group of Value-Added Tea (VAT) producing firms in Sri Lanka. The initial list of firms was drawn from the Ceylon Chamber of Commerce, Sri Lanka where 90 firms were registered under the category, tea in 1999. However, only 58 firms indicated that they were involved in VAT production in 1999. The number of firms in the sampling frame was further reduced to 47, after considering the subsidiary firms coming under a main company as part of the main company in conducting the survey. Personal interviews were conducted among 34 firms by using a pretested, structured questionnaire. Due to time restrictions, 4 firms sent their questionnaires by post and 2 via email. All these 6 firms were contacted again over the telephone in order to resolve inconsistent answers and complete unanswered questions. Although there were 47 firms engaged in VAT production in 1999, only 40 responded to the survey, giving a response rate of 85 per cent.

\section{Variable Measurement}

Previous studies have revealed that some of the variables have been used to explain both these views. This has created confusion in classifying which variable should be grouped under which view. Therefore, in the study variables that represent "what the firm has" were classified under the RBV, whereas variables that represent "what the firm does" were classified under the SBV. Further, as pointed out by most of the previous studies, only the specific strategically important resources and strategies were considered in the study. These core resources and strategies that can act as sources of competitive advantage 
were identified under six dimensions each.

Six dimensions of core resources that were selected for this study were scale, skill, brand equity, managerial talent, experience effects and backward integration. Scale economies were considered to be an important resource that leads firms to achieve competitive advantage (Bharadwaj et al, 1993; Ma, 2000). However, a number of studies have used different variables as proxies for scale. But in this study, size and the multibusiness nature of a firm were proxied through the variables, number of employees in tea and their involvement with businesses other than tea. Employee skills are commonly used in representing the superior skills possessed by a firm (De Vasconcellos and Hambrick, 1989; Hyvönen and Kola, 1995; Nakos et al., 1998). Similarly, in this study skilled employees in secondary processing and packaging (the two most important steps in adding value to tea) were considered in representing the skills possessed by a firm. According to Aaker (1991) brand equity consists of brand loyalty, name awareness, perceived quality, strong brand associations and other assets such as patents, trademarks, and channel relationships. Although a brand with strong brand equity is a valuable asset, its actual measurement is difficult (Kotler and Armstrong, 1995). Therefore, in addition to the ownership of a brand name, VAT production under own brand was used as a proxy for brand name awareness. Managerial capability is considered to be important in coordinating, integrating and reconfiguring multiple streams of competencies and deploying them strategically to exploit changing market opportunities (Govindarajan, 1989; Castanias, 1991). Therefore, managerial experience in tea related activities and managers' education level were used as proxies for managerial talent. Industry familiarity as measured by the length of experience in current and closely related industries is considered to be an important determinant of firms' performance (Govindarajan, 1989; Nakos et al., 1998). Therefore, firms' experience in VAT production was considered in representing experience effects. The last dimension, backward integration, is considered to be an important source of competitive advantage and innovation for firms (Porter, 1980; Cartwright, 1991). Therefore in this study, firms' ownership of tea plantations and/or primary tea processing facilities were considered as backward integration.

Similarly, six dimensions of core strategies - production, marketing, promotion, product innovation, 
quality and competitive strategy that are common to the majority of the industries were identified based on previous research. In terms of the production related strategies, many studies have considered a broad range of products, procurement of raw materials, capability of manufacturing speciality products and production method as important strategies (Dess and Davis, 1984; Hyvönen, 1995). Therefore, in this study five variables, outward foreign direct investments in VAT production, total tea imports, VAT production intensity (calculated based on proportion of VAT to total tea produced and expressed as a percentage), and perceived importance attached to secondary processing and packaging in achieving competitive advantage were considered as strategies that are related to production. Some previous studies have considered whether to market the product under manufacturers' brands, or private labels, what proportions to market under different brands and which markets to cater for as important strategies related to marketing (Hooley et al., 1992; Hyvönen and
Kola, 1995). Therefore, in order to represent this marketing dimension four variables; proportion of lowgrown and high-grown tea ${ }^{l}$ used in VAT production, proportion of brand marketing and proportion of tea exports, were used. Two variables, advertising intensity and use of trade fairs in promotion and seeking new markets, were selected to represent promotion-related strategies. These promotion strategies are considered to be highly important for a firm in achieving a competitive position over its rivals (Davies and Geroski, 1997; Nakos et al., 1998). Research and development intensity was used to represent the product development strategies of a firm, as this is considered to indicate its unique endowments, technological lead and advancement ahead of its competitors (De Vasconcellos and Hambrick, 1989; Cohen and Klepper, 1996; Porter, 1998). Quality is considered as a distinct dimension of competitive strategy and as an important process in a firm's operations that can lead it to develop competitive strengths over its rivals (Porter, 1980; Campbell-Hunt,

$1 \quad$ In Sri Lanka, the low-grown tea is strong and dark in colour and is usually marketed in countries where there is a high level of preference for strong tea. But high-grown tea is mild and lighter in colour and is usually marketed in countries where there is a higher level of preference for mild teas. Therefore, the type of tea used in producing VAT was considered as the best approach in measuring the targeted consumers in marketing VAT. 
2000). Therefore, in the study the adoption of the "Lion $\log o^{2 "}$ was considered to be a proxy for quality based strategies. Many studies have used the competitive strategies of a firm to capture its overall competitive position (Hooley et al., 1992; Hyvönen and Kola, 1995). Similarly, in this study three variables, namely, brand name and product innovation as the perceived basis of competitive advantage, emphasis on low-cost and differentiation in producing VAT were selected to represent the overall competitive strategy dimension of a firm.

\section{Results and Discussion}

Prior to the application of statistical techniques, multivariate outliers of the 10 core resource and 16 core strategy variables that were selected to represent the resource and strategy-based sources of competitive advantage of a firm were tested by using the Cook's distance statistic. An outlier, which represented one of the governmentowned organisations that produces a very low level of VAT, but which was backward integrated and represented a large number of employees, was deleted to overcome the influence of extreme values. This was considered to be important as the factor analysis is sensitive to outlying cases (Coakes and Steed, 1999). Later, the factor analysis the most commonly applied method in addressing the structure of variables (Child, 1970; Malhotra, 1999) — was performed separately for both sets of data by using the principal component technique. This created two smaller sets of standardised variables (a standardised variable is represented by a mean of 0 and standard deviation of 1) for subsequent multivariate analysis. Most importantly, the initial standardisation of variables was considered important as the original variables were measured in different units (Hoek and Esslemont, 1989; Krause et al., 1995). Further, the application of factor analysis to the original variables was especially useful in performing the canonical correlation as the application of factor scores for the canonical correlation analysis simplified the interpretation of results by having similar matrices of structure and canonical coefficients.

Results of the factor analyses after the varimax rotation revealed four underlying patterns of core resources and six underlying patterns

In Sri Lanka, the Tea Board allows printing of the Lion logo only if the quality of tea meets certain standards. Therefore, this was considered to be the best approximation for the quality strategy of firms. 
of core strategies. These explained $72 \%$ and $73 \%$ respectively of the cumulative variances of the models. The number of factors was retained by using a combination of eigenvalue, scree plot and cumulative proportion of variance. Criteria for the significance of factor loadings were considered to be \pm 0.394 (Child, 1970). The factor labellings were primarily done based on the high factor loadings and the results are presented in Tables 1 and 2.

Table 1: Varimax Rotated Factor Matrix - Core Resources

\begin{tabular}{|c|c|c|c|c|c|}
\hline \multirow[t]{2}{*}{ Variable } & \multicolumn{4}{|c|}{ Factor Loadings } & \multirow[t]{2}{*}{ Communality } \\
\hline & $\begin{array}{c}\text { Factor } \\
\text { One } \\
\text { Single } \\
\text { product- } \\
\text { skill based } \\
\left(\mathrm{R}_{1}\right)\end{array}$ & $\begin{array}{c}\text { Factor } \\
\text { Two } \\
\text { Firm size } \\
\text { and brand } \\
\text { awareness } \\
\text { based }\left(\mathrm{R}_{2}\right)\end{array}$ & $\begin{array}{c}\text { Factor } \\
\text { Three } \\
\text { Ownership } \\
\text { and } \\
\text { experience } \\
\text { based }\left(\mathrm{R}_{3}\right)\end{array}$ & $\begin{array}{c}\text { Factor Four } \\
\text { Professional } \\
\text { knowledge } \\
\text { based }\left(\mathrm{R}_{4}\right)\end{array}$ & \\
\hline $\begin{array}{l}\text { Number of skilled } \\
\text { employees in } \\
\text { secondary } \\
\text { processing }\end{array}$ & .861 & .204 & & & .789 \\
\hline $\begin{array}{l}\text { Number of skilled } \\
\text { employees in } \\
\text { packaging }\end{array}$ & .831 & .163 & & -.165 & .745 \\
\hline $\begin{array}{l}\text { Involvement with } \\
\text { businesses other } \\
\text { than tea }\end{array}$ & -.685 & .250 & & -.286 & .614 \\
\hline $\begin{array}{l}\text { Managerial } \\
\text { experience }\end{array}$ & .569 & .314 & .207 & -.374 & .605 \\
\hline $\begin{array}{l}\text { Ownership of a } \\
\text { brand name/s }\end{array}$ & -.485 & .187 & .482 & .149 & .525 \\
\hline $\begin{array}{l}\text { Total number of } \\
\text { employees in tea }\end{array}$ & .113 & .895 & .152 & & .846 \\
\hline $\begin{array}{l}\text { VAT production } \\
\text { under own brand } \\
\text { name/s }\end{array}$ & .176 & .835 & .260 & & .797 \\
\hline Years in VAT & -.226 & .621 & -.561 & & .753 \\
\hline $\begin{array}{l}\text { Backward } \\
\text { integration }\end{array}$ & & .213 & .756 & & .621 \\
\hline $\begin{array}{l}\text { Managerial } \\
\text { education }\end{array}$ & & .124 & & .926 & .876 \\
\hline Eigenvalue & 2.561 & 2.210 & 1.257 & 1.144 & \\
\hline Percent of variance & 25.611 & 22.096 & 12.566 & 11.435 & \\
\hline Cumulative percent & 26.611 & 47.707 & 60.273 & 71.708 & \\
\hline
\end{tabular}

Significant values are in bold 
Ariyawardana and Bailey. 2002. Sri Lankan Journal of Agricultural Economics. Volume 4. Part 1. Pp.1-18.

Table 2: $\quad$ Varimax Rotated Factor Matrix - Core Strategies

\begin{tabular}{|c|c|c|c|c|c|c|c|}
\hline \multirow[t]{2}{*}{ Variable } & \multicolumn{6}{|c|}{ Factor Loading } & \multirow[t]{2}{*}{ Communality } \\
\hline & $\begin{array}{c}\text { Factor One } \\
\text { VAT } \\
\text { production } \\
\text { oriented }\left(\mathrm{S}_{1}\right)\end{array}$ & $\begin{array}{c}\text { Factor Two } \\
\text { Consumer } \\
\text { preference } \\
\text { oriented }\left(\mathrm{S}_{2}\right)\end{array}$ & $\begin{array}{l}\text { Factor Three } \\
\text { Differenti-- } \\
\text { ation oriented } \\
\quad\left(\mathrm{S}_{3}\right) \\
\end{array}$ & $\begin{array}{c}\text { Factor Four } \\
\text { Exports and } \\
\text { quality oriented } \\
\left(\mathrm{S}_{4}\right)\end{array}$ & $\begin{array}{c}\text { Factor Five } \\
\text { Global strategy } \\
\text { oriented } \\
\left(\mathrm{S}_{5}\right) \\
\end{array}$ & $\begin{array}{c}\text { Factor Six } \\
\text { Brand and } \\
\text { cost oriented } \\
\left(\mathrm{S}_{6}\right)\end{array}$ & \\
\hline $\begin{array}{l}\text { Importance attached to secondary } \\
\text { processing }\end{array}$ & .867 & & & .111 & & & .786 \\
\hline Importance attached to packaging & .820 & .184 & & & .142 & & .735 \\
\hline Overall differentiation strategy & 696 & .305 & & .193 & & & 623 \\
\hline Proportion of high-grown tea & & .935 & .121 & & & & .893 \\
\hline Proportion of low-grown tea & -.167 & -.876 & -.137 & .176 & -.178 & .127 & .903 \\
\hline Research and development intensity & .179 & & .765 & & .118 & & .649 \\
\hline Advertising intensity & .287 & & .655 & -.393 & .192 & & .710 \\
\hline VAT production intensity & -.190 & .192 & .592 & .209 & -.149 & & .490 \\
\hline High perceived competitive advantage & & .178 & .501 & .271 & .472 & -.461 & .791 \\
\hline Use of trade fairs & .286 & .206 & .191 & .795 & -.215 & .101 & .849 \\
\hline Adoption of the Lion logo & .495 & -.168 & & 673 & & & .750 \\
\hline Proportion of tea exports & -.106 & -.260 & & .577 & .337 & .407 & 695 \\
\hline Tea imports & & & -.104 & -.190 & .835 & & .756 \\
\hline $\begin{array}{l}\text { Outward foreign direct investments in } \\
\text { VAT }\end{array}$ & .136 & .102 & .250 & .152 & .675 & & .576 \\
\hline Proportion of brand marketing & & .256 & .110 & & .155 & .797 & .740 \\
\hline Overall low-cost strategy & -.207 & -.308 & -.306 & -.133 & & .688 & .723 \\
\hline Eigenvalue & 2.500 & 2.162 & 1.887 & 1.865 & 1.704 & 1.551 & \\
\hline Percent of variance & 15.625 & 13.514 & 11.793 & 11.654 & 10.650 & 9.695 & \\
\hline Cumulative percent & 15.625 & 29.139 & 40.932 & 52.586 & 63.236 & 72.932 & \\
\hline
\end{tabular}

Significant values are in bold 
Results of the factor analysis with respect to core resources showed that the first factor is represented by the sources of competitive advantage, skilled employees, managerial experience and involvement with tea alone. However, the brand ownership as a source of competitive advantage negatively contributed to describing factor one. Therefore, factor one was labelled single product-skill based. Due to the high representation of sources of competitive advantage, size of the firm, brand awareness and experience in VAT by factor two, it was labelled firm size and brand awareness based. Factor three showed that the sources of competitive advantage, backward integration and brand ownership, positively contributed to describing factor three, whereas the experience in VAT as a source of competitive advantage negatively contributed to describing factor three. Therefore, it was labelled ownership and experience based. Factor four was explained only by the variable managerial experience and, as all the other variables showed an insignificant association, it was labelled professional knowledge based.

Results of the factor analysis with respect to core strategies showed that the first factor was highly positively associated with the sources of competitive advantage, importance attached to secondary processing and packaging and overall strategy differentiation. Thus, this factor was labelled VAT production oriented. Due to the high level of association of the variables that represented targeted consumers in marketing VAT, factor two was labelled consumer preference oriented. Factor three was highly positively associated with four of the sources of competitive advantage, research and development intensity, advertising intensity, VAT production intensity and highperceived competitive advantage. These four variables represented product development, promotion, production and overall strategy dimensions that could be considered extremely important for a firm in developing a unique position. Therefore, it was labelled differentiation oriented. Given the higher representation of sources of competitive advantages related to exports and quality, factor four was labelled exports and quality oriented. Factor five was positively associated with two of the sources of competitive advantage, tea imports and outward foreign direct investment. Both these variables showed the production and marketing strategy dimensions of a firm that is achieving, along with higher global integration; hence it was labelled global strategy 
oriented. The last factor was positively associated with only two variables, proportion of brand marketing and overall low-cost strategy. Therefore, it was labelled brand and cost oriented.

In order to assess the relationship between the two perspectives a canonical correlation analysis was performed by using the package SAS $^{\circledR}$ (the Cancorr procedure). Thereby, the degree to which the strategy patterns within firms could be accounted for by their resource patterns was examined. This technique was used mainly because the variables that are dependent consisted of more than one variable. The six strategy patterns that resulted from the factor analysis were considered as the dependent variables, and the four resource patterns that resulted from the factor analysis were considered as the independent variables in the analysis. This canonical correlation analysis forms a linear combination of independent $(\mathrm{X})$ variables, as a linear combination of dependent (Y) variables, which are known as canonical variates. The patterns of association within, and between, the two sets are important in identifying these linear combinations between two sets of variables. Therefore, it is essential to test the null hypothesis to determine whether or not the two sets of data are unrelated ${ }^{3}$. This was tested by using the test statistic Wilks' Lambda. The Wilks' Lambda value was 0.16 with an $F$-ratio of 2.93. It was significant at the probability level of 0.0001 . Therefore, the null hypothesis that two sets of data are unrelated must be rejected. This showed that the two sets of data were significantly related. Since the analysis used two sets of factors as dependent and independent variables ${ }^{4}$, within-set correlation matrices were identity matrices. However, the matrix of intercorrelations between the two sets of variables revealed high positive correlations among few variables (Table 3). $S_{5}$ and $R_{2}$ were highly positively correlated with a

According to Clark (1975, p. 17), the null hypothesis that the two sets of data are unrelated is tested by use of the chi-square. The test statistic is known as Wilks' Lambda and is derived from the canonical variates.

4 According to Wollenberg (1977, p. 212), when two sets of factors are used in the analysis the explained variance of the variables in each set is a maximum. According to Levine (1977, p. 34), submitting two sets of factor scores to canonical correlation analysis eliminates the problem of difference between the weights (canonical coefficients) and structure matrix. But the canonical variates will be composites of composites - leading to interpretation difficulties. 
coefficient of 0.65 (strategy pattern, global strategy oriented and resource pattern, firm size and brand awareness based). The second highest correlation of 0.41 was seen between the variables $S_{3}$ and $R_{3}$ (strategy pattern, differentiation oriented and resource pattern, ownership and experience based).

The canonical analysis with 6 dependent and 4 independent variables resulted in four pairs of canonical variates (since the number of variables in the smaller set of data was four, four pairs of canonical variates resulted). The first pair of canonical variates provided the maximum possible correlation and the canonical correlation $\left(r_{c}\right)$ was 0.83 . This indicated that these two canonical variates were strongly correlated (the $r_{c}$ ranges from 0 to +1.0 ). The other three pairs of canonical variates showed canonical correlations of $0.59,0.42$ and 0.19 respectively. Although four pairs of canonical variates resulted, their importance was considered through the significance of canonical variates. The $F$-test results showed that only the first pair of canonical variates was significant at the probability level of 0.0001 . Therefore, the interpretation was based only on the first pair of canonical variates. Similarly, the eigenvalues also indicated that only the first pair explains the highest total variance that two sets have in common. The relevant statistics are presented in Table 4.

Table 3: $\quad$ Correlation Matrix - Strategy and Resource Patterns

\begin{tabular}{lcccc}
\hline & $\mathrm{R}_{1}$ & $\mathrm{R}_{2}$ & $\mathrm{R}_{3}$ & $\mathrm{R}_{4}$ \\
\hline $\mathrm{S}_{1}$ & 0.0712 & 0.1408 & 0.1633 & 0.1450 \\
$\mathrm{~S}_{2}$ & -0.0124 & -0.0407 & 0.2523 & -0.1121 \\
$\mathrm{~S}_{3}$ & 0.0813 & 0.2935 & 0.4059 & -0.0550 \\
$\mathrm{~S}_{4}$ & 0.0325 & 0.1794 & 0.2124 & -0.1312 \\
$\mathrm{~S}_{5}$ & 0.0964 & 0.6537 & -0.1737 & 0.1384 \\
$\mathrm{~S}_{6}$ & -0.3747 & 0.2778 & 0.1303 & 0.1480 \\
\hline
\end{tabular}


Table 4: $\quad$ Matrices of Canonical Coefficients ${ }^{\mathrm{a}}$ and Related Statistics

\begin{tabular}{ccccc}
\hline & $\mathbf{Y}_{\mathbf{1}}$ & $\mathbf{Y}_{\mathbf{2}}$ & $\mathbf{Y}_{\mathbf{3}}$ & \multicolumn{1}{c}{$\mathbf{Y}_{\mathbf{4}}$} \\
\hline $\mathrm{S}_{1}$ & 0.2359 & 0.1414 & 0.0671 & 0.8470 \\
$\mathrm{~S}_{2}$ & 0.0016 & 0.4695 & 0.0101 & -0.1664 \\
$\mathrm{~S}_{\mathbf{3}}$ & 0.4399 & 0.5810 & 0.2311 & 0.0862 \\
$\mathrm{~S}_{4}$ & 0.2396 & 0.3483 & 0.1758 & -0.4742 \\
$\mathrm{~S}_{5}$ & 0.7319 & -0.5447 & 0.2775 & -0.1410 \\
$\mathrm{~S}_{6}$ & 0.3972 & 0.0642 & -0.9133 & -0.0520 \\
& & & & \\
\% Variance explained by own variables & 16.67 & 16.67 & 16.67 & 16.67 \\
& & & & \\
& & & & \\
$\mathrm{R}_{1}$ & -0.0216 & -0.0234 & 0.9498 & 0.3111 \\
$\mathrm{R}_{2}$ & 0.9578 & -0.1767 & 0.0861 & -0.2096 \\
$\mathbf{R}_{3}$ & 0.2328 & 0.9380 & -0.0539 & 0.2510 \\
$\mathbf{R}_{4}$ & 0.1670 & -0.2972 & -0.2958 & 0.8923 \\
& & & & \\
\% Variance explained by own variables & 25.00 & 25.00 & 25.00 & 25.00
\end{tabular}

\section{Redundancy Coefficients}

\begin{tabular}{|c|c|c|c|c|c|c|c|}
\hline Variate & $r_{c}$ & $r_{c}^{2}$ & Eigenvalue & Appro $F$ & $\operatorname{Pr}>\boldsymbol{F}$ & $\mathbf{Y}$ & $\mathbf{X}$ \\
\hline 1 & 0.829 & 0.687 & 2.197 & 2.926 & 0.0001 & 0.1145 & 0.1718 \\
\hline 2 & 0.591 & 0.349 & 0.536 & 1.499 & 0.1244 & 0.0582 & 0.0873 \\
\hline 3 & 0.419 & 0.176 & 0.213 & 0.948 & 0.4842 & 0.0293 & 0.0439 \\
\hline 4 & 0.192 & 0.037 & 0.039 & 0.410 & 0.7466 & 0.0062 & 0.0093 \\
\hline Total & & & & & & 0.2082 & 0.3123 \\
\hline
\end{tabular}

${ }^{\mathrm{a}}$ Standardised canonical coefficients

As pointed out earlier, both variable $S_{5}$ (global strategy oriented) matrices of canonical coefficients has contributed most to the first and canonical structure ${ }^{5}$ were similar variate - and it also showed the as the analysis was conducted by highest correlation with the variate. using factor scores. This has avoided The least contribution was given by problems in interpretation. the strategy pattern $S_{2}$ (consumer According to Table 4, it is clear that, preference oriented). Similarly, among the strategy patterns, the among the resource patterns the

The matrix of canonical coefficients show the direct contribution of each variable to the composite, whereas the matrix of canonical structure shows the correlation of the original variables with the canonical variates. 
variable $R_{2}$ (firm size and brand awareness based) has contributed most to the first variate, and it also showed the highest correlation with the variate. The least contributed resource pattern was $\mathrm{R}_{1}$ (single product-skill based). Initially, this high association was clearly evident from the correlation coefficient of 0.65 between $S_{5}$ and $R_{2}$.

The redundancy coefficients were calculated based on the canonical structure in the canonical correlation analysis as it is important in determining how much of the variability of one set of variables is explained by the other. Results of the analysis showed that only $17 \%$ of the variance of the dependent set of variables $(\mathrm{Y})$ and $25 \%$ of the variance of the independent set of variables $(\mathrm{X})$ were captured by the first pair of canonical variates (Table 4). The first pair has captured a higher variance from the resource patterns than the strategy patterns in the model. This was evident also from the higher contribution of $\mathrm{R}_{2}$ to the first pair of variates - unlike the strategy patterns. However, the redundancy coefficients ${ }^{6}$ showed that only a proportion of $11 \%$ of the variance in the dependent set was explained by the first variate of the independent set of variables. Over the four solutions, a proportion of $21 \%$ of the variance of the dependent set was explained by the four variates of the independent set of variables. This conclusion seems to be intuitively clear and it is further proved by the canonical $R$-squared $\left(r_{c}^{2}\right)$. According to Levine (1977), the canonical $R$-squared $\left(r_{c}^{2}\right)$ in the redundancy analysis shows the share of the variance of one set which can be accounted for by a canonical variate from the other set, or the proportion of the variance of one variate which overlaps the other. Therefore, the $r^{2}$ value of 0.687 pointed out that the first variate of the Y set of variables shares $69 \%$ of its variance with the first variate of the $\mathrm{X}$ set of variables. This showed that, even though the first variate of the Y set of variables captures $17 \%$ of the variance of the dependent set of variables, it shares $69 \%$ of its variance with the first variate of the independent set. (This also proves that the first variate of the resource patterns explains only $11 \%$ of the variance of the strategy patterns). But only the first variate has extracted a considerable share of variance from the dependent set of variables, and in all the other variates the independent set of variables shared the most.

6. These show the proportion of variance explained by the opposite canonical variables. 


\section{Conclusions}

On the whole, the results of the canonical correlation analysis indicated that there is a significant link between the resource and strategy patterns. This was evident from the statistical significance of the first pair of canonical variates. Even though there was a significant link between the resource and strategy patterns, the first canonical variate of the resource patterns explained only $11 \%$ of the variance in the strategy patterns. Overall, the resource patterns explained a proportion of $21 \%$ of the variance of the strategy patterns of the VAT producing firms in Sri Lanka. However, it could be pointed out that, in general, strategy implementation by the VAT producing firms was weakly explained by the core resource availability of firms. That is, both Sri Lankan VAT producing firms' choice of strategy and their ability to perform a particular strategy are weakly associated with their core resource strength. Therefore, this study implies that firms should give a greater emphasis in uplifting their resource strength with a view to enhancing their performance.

The implication of this for future analysis of firm performance will be that it illustrates the need to assess firm performance through both resource and strategy patterns. Results of the empirical analysis also supported the views of Hannes and Fjeldstad (2000) who have raised the matter of importance of incorporating both these perspectives. If the strategy patterns had been highly conditional upon the resource patterns, then the assessment of performance through the strategy-performance relationship would have provided a broader understanding about firm performance. But due to the weaker relationship between strategy and resource perspectives, an integrated approach that combines both RBV and SBV will provide a better explanation of firm performance.

\section{References}

Aaker, D.A. (1991). Managing Brand Equity: Capitalising on the Value of a Brand Name. New York: The Free Press.

Barney, J. (1991). Firm Resources and Sustained Competitive Advantage. Journal of Management, 17 (1):99-120.

Bharadwaj, S.G., P.R. Varadarajan and J. Fahy (1993). Sustainable Competitive Advantage in Service Industries: A Conceptual Model and Research 
Propositions. Journal of Marketing, 57:83-99.

Campbell-Hunt, C. (2000). What have We Learned about Generic Competitive Strategy? A Meta-analysis. Strategic Management Journal, 21:127-154.

Cartwright, W. (1991, August). International Competitiveness of Landbased Industries: Approach to Research. A Paper Presented at the New Zealand Branch of the Australian Agricultural Economics Society, $16^{\text {th }}$ Annual Conference, Lincoln University, New Zealand. (Discussion Paper, 131:1$15)$.

Castanias, R.P. (1991). Managerial Resources and Rents. Journal of Management, 17 (1): 155-171.

Child, D. (1970). The Essentials of Factor Analysis. London: Holt, Rinehart and Winston Ltd.

Clark, D. (1975). Understanding Canonical Correlation Analysis. Concepts and Techniques in Modern
Geography No. 3. Norwich: University of East Anglia.

Coakes, S.J. and Steed, L.G. (1999). SPSS: Analysis Without Anguish. Australia: John Wiley and Sons Australia, Ltd.

Cohen, W.M. and S. Klepper (1996). Firm Size and the Nature of Innovation within the Industries: The Case of Process and Product Research and Development. The Review of Economics and Statistics, 78(2):232243.

Collis, D.J. (1994). Research Note: How Valuable are Organisational Capabilities? Strategic

Management Journal, 15:143-152.

Davies, S.W. and P.A. Geroski (1997). Changes in Concentration, Turbulence, and the Dynamics of Market Shares. The Review of Economics and Statistics, 79(3): 383-391.

Day, G.S. and R. Wensley (1988). Assessing Advantage: A Framework for Diagnosing Competitive Superiority. Journal of Marketing, 52:120. 
De Vasconsellos, J.A.S. and D.C.

Hambrick. (1989). Key

Success Factors: Test of a

General Theory in the

Mature Industrial-product

Sector. Strategic

Management Journal, 10: 367-382.

Dess, G.G. and P.S. Davis (1984). Porter's (1980) Generic Strategies as Determinants of Strategic Group Membership and Organisational Performance. Academy of Management Journal, 27(3) :467-488.

Dess, G.G., G.T. Lumpkin and J.G. Covin (1997). Entrepreneurial Strategy Making and Firm Performance: Tests of Contingency and Configurational Models. Strategic Management Journal, 18:677-695.

Faulkner, D. and C. Bowman (1992). Generic Strategies and Congruent Organisational Structure: Some Suggestions. European Management Journal, 10 (4):494-499.

Govindarajan, V. (1989). Implementing Competitive Strategies at the Business
Unit Level: Implications of Matching Managers to Strategies. Strategic Management Journal, 10:251-269.

Grant, R.M. (1991). The Resourcebased Theory of Competitive Advantage: Implications for Strategy Formulation. California Management Review, 33(3): 114-135.

Haanes, K. and Ø. Fjeldstad (2000). Linking Intangible Resources and Competition. European Management Journal, 18 (1):52-62.

Hendry, J. (1990). The Problem with Porter's Generic Strategies. European Management Journal, 8(4):443-450.

Hoek, J.A. and D.H.B. Esslemont (1989). Limitations of the Use of Cluster Analysis in Market Segmentation Studies. New Zealand Journal of Business, 11:8288.

Hooley, G.J., J.E. Lynch and D. Jobber (1992). Generic Marketing Strategies. International Journal of Research in Marketing, 9:7589. 
HyvØnen, S. (1995). Competitive Advantage, Bargaining Power and Organisational Performance: The Case of Finnish Food Manufacturing Firms. Agribusiness, 11(4): 333-348.

HyvØnen, S. and J. Kola (1995). The Finnish Food Industry Facing European Integration: Strategies and Policies. European Review of Agricultural Economics, 22(3) :296-309.

Kamalesh, K., R. Subramanian and C. Yauger (1997). Pure Versus Hybrid: Performance Implications of Porter's Generic Strategies. Health Care Management Review, 22(4) :47-60.

Kotler, P. and G. Armstrong. (1995). Principals of Marketing (6th ed.). New Delhi: PrenticeHall.

Krause, J. H., W.W. Wilson and F.J. Dooley (1995). Global Market Segmentation for Value-added Agricultural Products. Agribusiness, 11(3):195-206.

Levine, M.S. (1977). Canonical Analysis and Factor
Comparison. USA: Sage Publications, Inc.

Ma, H. (2000). Of Competitive Advantage: Kinetic and Positional. Business Horizons, 43(1):53-64.

Majumdar, S.K. (1998). On the Utilisation of Resources: Perspective from the US Telecommunication Industry. Strategic Management Journal, 19:809-831.

Malhotra, N. K. (1999). Marketing Research: An Applied Orientation (3rd ed.) New Jersey: Prentice-Hall.

Miller, A. and G.G. Dess (1993). Assessing Porter's (1980) Model in Terms of Its Generalisability, Accuracy and Simplicity. Journal of Management Studies, 30(4): 553-585.

Miller, D. and J. Shamsie (1996). The Resource-based View of the Firm in Two Environments: The Hollywood Film Studios from 1936 to 1965. Academy of Management Journal, 39(3) :519-543. 
Miller, D. (1992). The Generic Strategy Trap. The Journal of Business Strategy, 13:3741.

Nakos, G., K.D. Brouthers and L.E. Brouthers (1998). The Impact of Firm and Managerial Characteristics on Small and Medium-sized Greek Firm's Export Performance. Journal of Global Marketing, 11(4):2347.

Peteraf, M.A. (1993). The Cornerstones of Competitive Advantage: A Resourcebased View. Strategic Management Journal, 14:179-191.

Phillips, L.W., D.R. Chang and R.D. Buzzell (1983). Product Quality, Cost Position and Business Performance: A Test of Some Key Hypotheses. Journal of Marketing, 47(2): 26-43.

Porter, M.E. (1980). Competitive Strategy: Techniques for Analysing Industries and Competitors. New York: The Free Press.
Porter, M.E. (1998). The Competitive Advantage: Creating and Sustaining Superior Performance with a New Introduction. New York: The Free Press.

Wagner, B. and L. Digman (1997). The Relationships between Generic and Time-based Strategies and Performance. Journal of Managerial Issues, 9(3):334-354.

Wernerfelt, B. (1984). A Resourcebased View of the Firm. Strategic Management Journal, 5:171-180.

Wolff, J.A. and T.L. Pett (2000). Internationalisation of Small Firms: An Examination of Export Competitive Advantage Patterns, Firm Size, and Export Performance. Journal of Small Business Management, 38 (2):34-47.

Wollenberg, A.L. (1977). Redundancy Analysis: An Alternative for Canonical Correlation Analysis. Psychometrika, 42(2):207219. 